\title{
Geothermal bathing and recreation centres in Poland
}

\author{
Elzbieta Halaj
}

Received: 30 December 2013/ Accepted: 24 September 2014/Published online: 11 October 2014

(C) The Author(s) 2014. This article is published with open access at Springerlink.com

\begin{abstract}
Ten geothermal bathing and recreation centres have been established in Poland from 2006 to 2013. The largest number of geothermal bathing and recreation centres is located in the Podhale region and in the Polish Lowlands. These structural units have the best geothermal conditions. The maximum reservoir's temperatures in the main aquifer of the Podhale Geothermal System can reach ca. $120-128{ }^{\circ} \mathrm{C}$ in the deeper parts of the system. The most prospective and exploited aquifers occur within the Middle Triassic formations and in overlaying Middle Eocene formations at the depth of 1,000-3,700 m. At present, five operating centres are located in the Podhale region. They use geothermal waters with the temperature of $27-82{ }^{\circ} \mathrm{C}$ (the lowest and the highest wellhead temperature of water from wells which are connected for recreational purposes) and total dissolved solids (TDS) of $0.4-3 \mathrm{~g} / \mathrm{dm}^{3}$. In the Polish Lowlands, the reservoir's temperatures vary from 20 to $130{ }^{\circ} \mathrm{C}$ at depths of $1-4 \mathrm{~km}$. The most prospective geothermal aquifers of the Polish Lowlands occur within the Lower Cretaceous and the Lower Jurassic formations. Five geothermal recreation centres are currently operating. The centres use waters with the temperature of $38-72{ }^{\circ} \mathrm{C}$ and a wide range TDS from 0.4 to $79 \mathrm{~g} / \mathrm{dm}^{3}$. Geothermal waters of the Polish Lowlands are generally high in $\mathrm{Na}$ and $\mathrm{Cl}$ concentrations. The new centres will use the waters of Lower Jurassic aquifers, the outflow temperatures of which vary from 27 to $82{ }^{\circ} \mathrm{C}$ and a TDS from 6 to $140 \mathrm{~g} / \mathrm{dm}^{3}$.
\end{abstract}

Keywords Geothermal waters - Bathing centres . Recreation centres · Poland

E. Halaj $(\bowtie)$

AGH University of Science and Technology,

A. Mickiewicza 30 Ave., 30-059 Krakow, Poland

e-mail: elzbieta.halaj@gmail.com

\section{Introduction}

Geothermal heat capacity for use in balneotherapy and recreation in Poland is $11.5 \mathrm{MWth}$ and heat production is $36.30 \mathrm{GWhth} /$ year, which is about $10 \%$ of the total capacity and $20 \%$ of the total heat production in geothermal direct use in Poland (Antics et al. 2013). It corresponds to worldwide geothermal direct utilization percentage of 13.8 and $25.8 \%$, respectively (Lund et al. 2011). Additionally, recreation is one of the most promising sectors of geothermal energy in Poland. In 2013, heat consumption from geothermal waters for recreational purposes was 26.7 GWhth/year (Kępińska 2013), which is three times higher than heat consumption for balneotherapy.

The largest number of geothermal bathing and recreation centres in Poland is located in the Podhale Trough and the Polish Lowlands. These are two structural units, which have the best geothermal conditions-a high water temperature, low total dissolved solids (TDS) levels, great porosity and permeability of the aquifer's rock, etc. Aquifer formations of both units are represented significantly by Mesozoic sediments with good hydrogeological conditions. Plans for establishing some new geothermal centres in these units are also being made.

The Podhale Trough belongs to the most prospective areas for geothermal energy use in Poland. Moreover, it is located in a very attractive touristic area, which generates demand for geothermal bathing and recreation. The Podhale geothermal system was properly recognized from the geological point of view. Hydrogeological and geothermal conditions of the Podhale Trough were explored due to analyses conducted in 21 boreholes (Chowaniec 1997, 2004, 2009; Kępińska 1997, 2006; Małecka 2003), including the newest borehole in Bańska, drilled in 2013 and a 3D seismic survey (Górecki 2011). 
The Polish Lowlands is located on about $80 \%$ of territory of Poland. Lower Cretaceous and Lower Jurassic formations demonstrate the best hydrogeological conditions for geothermal water occurrence. Furthermore, waters from both the Lower Cretaceous and Lower Jurassic aquifers contain significant amounts of iodine and bromine ions as well as potassium and magnesium ions, which make them potentially useful for balneotherapeutical purposes (Górecki 2006). Geothermal resources in the Polish Lowlands have been assessed by Górecki (1995, 2006). Geothermal waters have been studied e.g. by Bojarski et al. (1976), Dowgiałło et al. (2007) and Paczyński and Sadurski ( 2007).

The investigation of waters used for balneotherapeutic purposes is more detailed than water for recreational purposes. It is determined by the fact that geothermal waters in Poland were applied in medicine much earlier than in organized recreational centres. The history of the application of geothermal water in balneotherapy in Lądek Zdrój (The Sudety Mts.) goes back to the twelfth century (Ciężkowski et al. 2010). Several balneological materials, including geothermal medicinal waters, have been classified by Dowgiałło et al. (1969). In Poland, there are nine registered health resorts operating, which use geothermal waters for therapy (Kepinska 2001, 2013), and which are used for both curing of diseases and preventive therapy (Lund 2009). The application of geothermal water in recreation has been known before the growth of geothermal recreational centres in Poland from Slovakia, where such application is popular. In Slovakia, there were 160 geothermal recreational swimming pools in 2005 (Kriš 2005). The occurrence of geothermal waters in Slovakia is in Triassic carbonates (limestones and dolomites) and Neogene psammites and psephites (Kriš et al. 1995). In recent years, the interest in recreational use of geothermal waters in Poland has increased (Kępińska and Łowczowska 2002; Latour 2007; Latour and Drobnik 2010), however, there is no up to date comparison of geothermal waters used in recreation made yet.

The goal of this paper is to identify parameters of geothermal waters used for recreational purposes in different areas of Poland and provide hydrogeological and some technical background for the current and planned use of geothermal waters in recreation in Poland. As a result, the comparison of main parameters of water occurrence between geological structures where geothermal recreational centres are located will be provided.

\section{Materials and methods}

For identification and comparison purposes, geothermal waters that are used in geothermal recreational centres were selected. A geothermal recreational centre is considered a swimming pool or a group of swimming pools, where at least one of them is a thermal swimming pool and it is not a health resort spa. A thermal swimming pool is defined by Kriš (2005) as a swimming pool filled with geothermal mineral water in more than $50 \%$ of the volume. If the mineralization limit of $5,000 \mathrm{mg} / \mathrm{dm}^{3}$ is exceeded, the amount of geothermal water can be lower than $50 \%$.

The above-mentioned condition is fulfilled in case of wells, from which the water is used in 10 recreational centres. All centres are located in two geological units: the Podhale Trough and the Polish Lowlands. Waters under consideration come from the main wells, which operate in the centres. Geothermal springs are not present in the recreational centres and all waters are delivered from deep wells, the depth of which exceeds $1,000 \mathrm{~m}$. The location map of the study area with the existing and planned centres is shown in Fig. 1.

The analysed chemical data come from published materials and unpublished documentation of wells (No. 9). For two wells (No. 1 and No. 2), the analysis of major chemical components was available, while eight wells were analysed for both major chemical components and trace elements. The identification of the remaining parameters of water, aquifers and technical conditions of recreational centres was also made on the basis of published materials and information.

Waters are classified based on their hydrochemical composition. Comparative analysis was conducted to compare geothermal waters from the two geological units. Parameters of waters coming directly from the deep wells were taken for the analysis, irrespective of their final proportion in a swimming pool. In case of simultaneous or prior application of geothermal waters for other purposes than recreation (e.g. for space heating), parameters of raw water from the well (e.g. temperature, flow rate) were taken for the analysis.

Geological and geothermal characteristics of the study area

The average geothermal gradient of the area of Podhale geothermal system varies between 1.9 and $2.4{ }^{\circ} \mathrm{C} / 100 \mathrm{~m}$; however, there are some surface anomalies detected in the northern part of the system. The reservoir's maximum temperatures in the main aquifer are $90-95^{\circ} \mathrm{C}$ and $120-128^{\circ} \mathrm{C}$ in the deeper parts of the system at a depth of 4,500-4,800 m. Waters come from wells with an artesian outflow with flow rates of $4-550 \mathrm{~m}^{3} / \mathrm{h}$. The total dissolved solids (TDS) of the geothermal waters vary from 0.1 to $3.2 \mathrm{~g} / \mathrm{dm}^{3}$ (Kępińska and Wieczorek 2011).

Geothermal waters were found under the Flysch formations in boreholes, the depth of which exceeds $1,000 \mathrm{~m}$. 
Fig. 1 Location map of the study area for existing and planned geothermal bathing and recreational centres in Poland

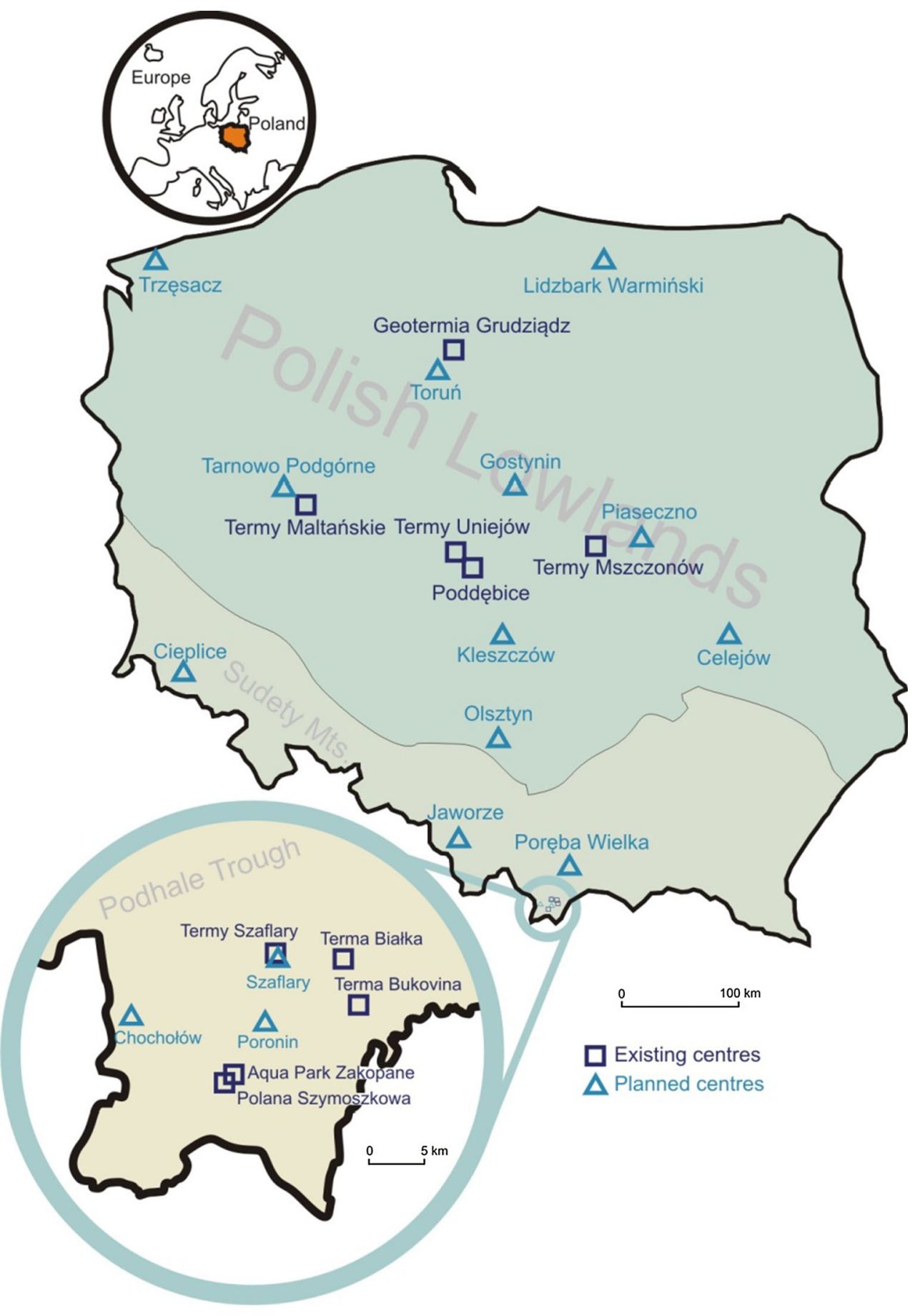

The system has a network of faults. The geothermal waters come mostly from rocks with a secondary fractured porosity which increases in near-fault zones. The aquifer rocks' secondary fractured porosity is 10-20\% with an intrinsic permeability of up to $1,000 \mathrm{mD}$ (Kępińska and Wieczorek 2011). The water in the Podhale Trough is under artesian condition (Chowaniec 2009). The geothermal system recharge zone is a part of the uplifted Tatra Mountains massif. It has an area of ca. $350 \mathrm{~m}^{2}$.
The geothermal system is build from two basic Mesozoic (Triassic-Cretaceous) and Tertiary (Palaeogene) formations which form a structural trough (Fig. 2). Rocks of the geothermal water reservoir are mainly Triassic carbonates, Jurassic sandstones and carbonates. The most prospective and exploited aquifers occur within the Middle Triassic limestone and dolomites and in overlaying Middle Eocene carbonates at a depth of 1,000-3,700 m. Their total thickness is up to 2,500 m and 100-700 m, respectively (Kępińska and Wieczorek 2011). 


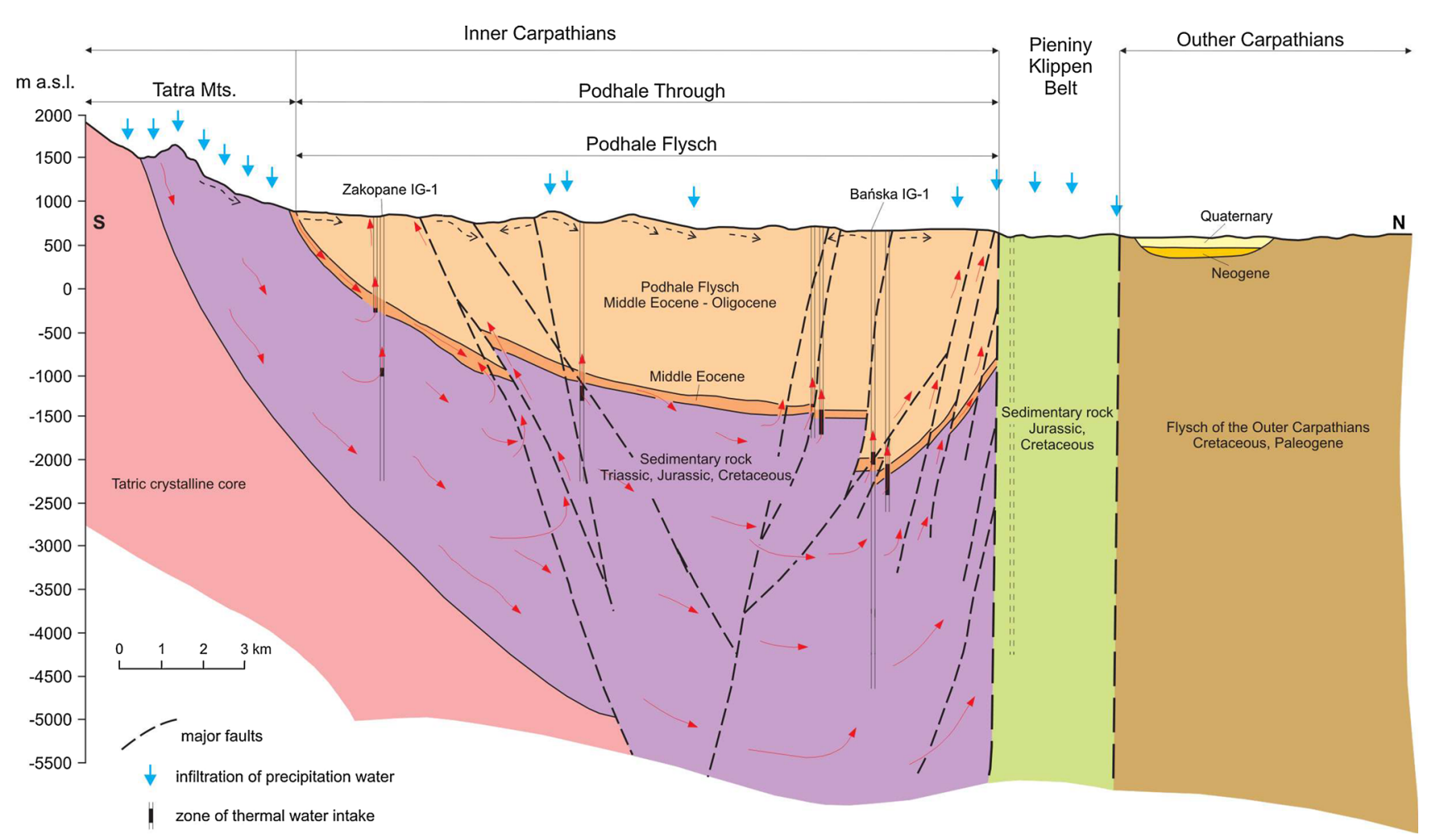

Fig. 2 Hydrogeological cross-section of the Podhale Trough (Chowaniec 2009)

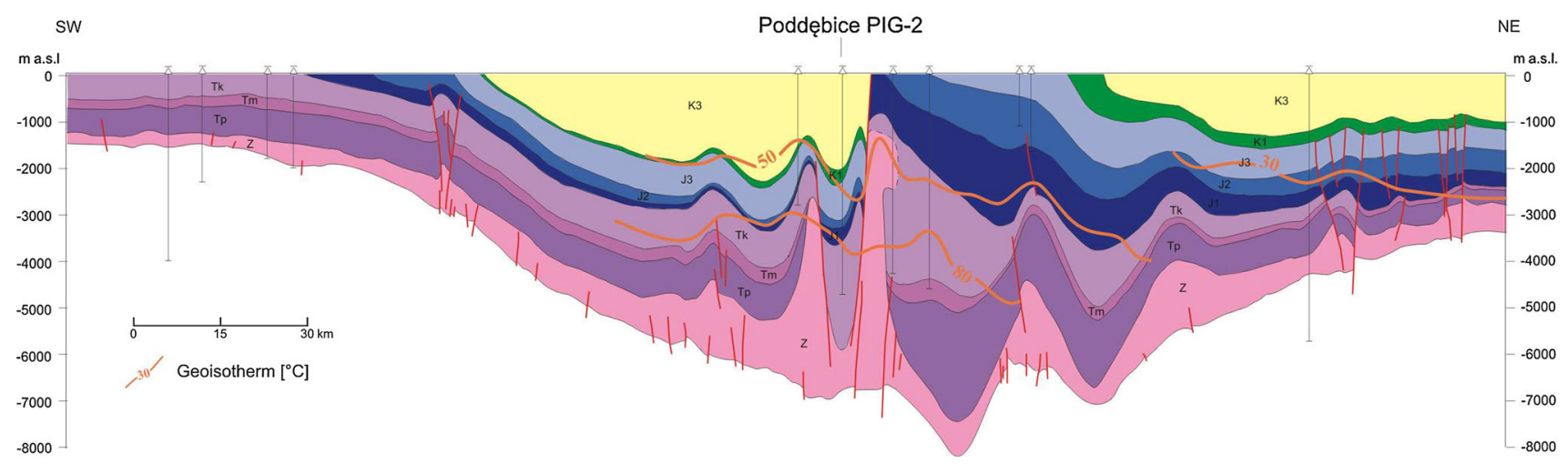

Fig. 3 Geological cross-section through the Polish Lowlands in the area of Geotermia Poddębice and Termy Uniejów centres (Hajto 2006)

The Polish Lowlands are an intercratonic deep, which are formed by Paleozoic and Mesozoic sediments overlain by a thin Cenozoic cover (Fig. 3). The deepest part of the Paleozoic platform reaches $20 \mathrm{~km}$ of thickness of the sedimentary cover. However, sediments are thinner in the Precambrian craton and their thickness varies from 200 to $500 \mathrm{~m}$ in the north-eastern Poland. There are two main structural units. The lower unit is of the Cambrian to Silurian age, while the upper unit is of Permian to Cenozoic age (Górecki 2006). The plastic Zechstein salts (Upper Permian) which formed pillow and diapire structures, which were deformed due to Laramian tectonic movements, are characteristic for this area. Zechstein salt layer was pressed up to the surface and crossed almost $6 \mathrm{~km}$ thick overlying Triassic, Jurassic and Cretaceous deposits. Dowgiałło (2012) considers that the TDS (mineralization) of water may be connected with leaching of salt structures by groundwater, marine connate waters present in the Triassic and Jurassic sediments, or contribution of meteoric waters infiltrated in warmer continental periods of Neogene.

The average geothermal gradient in the Polish Lowlands formations is $2.5^{\circ} \mathrm{C} / 100 \mathrm{~m}$. The distribution of its values 
corresponds to boundary values of the heat flow in the area, and changes from $1.6{ }^{\circ} \mathrm{C} / 100 \mathrm{~m}$ in the North-Eastern part of the Polish Lowlands to $3.0{ }^{\circ} \mathrm{C} / 100 \mathrm{~m}$ in the NorthWestern part, respectively. Local temperature inversions occur in the North-Eastern area of the Polish Lowlands (Górecki 2006).

The Lower Cretaceous water reservoir is of a porouschinky type, consisting mainly of permeable sandy, sandymarly, sandy-muddy sediments, the total cumulative thickness of which varies from 150 to $300 \mathrm{~m}$. The effective porosity of sandstone is $11.4-31.6 \%$; however, the reservoir could be considered as less continuous according to the Liassic aquifer (Górecki 2006). The TDS of the water ranges from $2 \mathrm{~g} / \mathrm{dm}^{3}$ (along outcrops of subunits) to $20 \mathrm{~g} /$ $\mathrm{dm}^{3}$ (in central part of subunits), and increases locally to even more than $100 \mathrm{~g} / \mathrm{dm}^{3}$.

The Lower Jurassic (Liassic) reservoir is built from nonequigranular sands and sandstones with a highly varied thickness and permeability. The permeable rocks fill $40-80 \%$ of Liassic lithological profile. The permeable rocks are interbedded with semipermeable or impermeable claystones, sandy claystones, mudstones and sandy mudstones. The thickness of the aquifer may reach from 0 to more than $800 \mathrm{~m}$. The TDS of the water from the reservoir varies from 0.2 to $200 \mathrm{~g} / \mathrm{dm}^{3}$ (Górecki 2006). The highest mineralization is observed in the deepest parts of the reservoir. The lowest TDS values occur along the southern and eastern margins, where the geothermal water reservoir is simultaneously a reservoir of high-value potable water.

\section{Results and discussion}

Geothermal bathing and recreation centres in Podhale

The Podhale Trough is located in the south of Poland, surrounded by the Tatra Mountains and the Pieniny Klippen Belt geostructural units, some well-known touristic attractions. Five geothermal recreational bathing centres operate in the area of the Podhale region. Geothermal energy is particularly used for district heating in the area of the city of Zakopane and several villages.

In its early stages, in the nineteenth century, the use of geothermal water in Podhale was limited to bathing in geothermal water coming from a natural warm spring in Jaszczurówka near Zakopane. Then, a geothermal bathing was possible in water exploited from two artificial wells drilled in the 1970s and directed to outdoor pools. Aqua Park Zakopane was established on the basis of existing wells in 2006. Water from the Zakopane IG-1 well, the only one which supplies the centre recently, has wellhead temperature of $36{ }^{\circ} \mathrm{C}$ and comes from Jurassic marls and marl carbonates with cherts. Its flow rate is $50 \mathrm{~m}^{3}$. Water from the well comes directly to an outdoor swimming pool with an area of $400 \mathrm{~m}^{2}$ and has temperature of $30.5^{\circ} \mathrm{C}$. The water is $\mathrm{HCO}_{3}-\mathrm{Ca}-\mathrm{Mg}$ type and has a very low TDS, not exceeding $0.4 \mathrm{~g} / \mathrm{dm}^{3}$ (http://www.aquapark.zakopane. pl, accessed 1 December 2013). Due the fact that water has a $\mathrm{H}_{2} \mathrm{~S}$ content at the level of $2 \mathrm{mg} / \mathrm{dm}^{3}$, the pool is considered to be a recreational-therapeutic one. The entire centre is heated by geothermal energy.

The next geothermal swimming pool in Zakopane is located in Polana Szymoszkowa - a glade with a double outdoor pool filled with $\mathrm{HCO}_{3}-\mathrm{Cl}-\mathrm{Ca}-\mathrm{Mg}-\mathrm{Na}$ type water. The water has the wellhead temperature of $27.3^{\circ} \mathrm{C}$ (Kępińska and Wieczorek 2011) and a TDS of $0.38 \mathrm{~g} / \mathrm{dm}^{3}$ (Dinh et al. 2010). The water in the pool is additionally heated by energy delivered from a geothermal heating plant (PEC Geotermia Podhalańska) and from a heat pump installed in the centre. The Polana Szymoszkowa swimming pool was opened in 2007 as a pool where water was heated only by geothermal energy. Since 2009, the geothermal water is delivered to the pool from a well reaching the Palaeogene, Triassic and Jurassic formations lying at a depth of 1,112-1,663 m (Kępińska and Wieczorek 2011).

A space heating service is operated by the geothermal heating plant located $17 \mathrm{~km}$ from the city for most of the public utility buildings, hotels and several dwellings in Zakopane. The heating plant uses the water which has a temperature of $82-86{ }^{\circ} \mathrm{C}$. The water is exploited from two wells which reach Palaeogene and Triassic aquifers at a depth of 2,565-3,345 m (Kępińska and Wieczorek 2011). Recently, a third newly drilled well has been connected to the system. Water is directed to heat exchangers where its temperature is decreased, although the chemical composition does not change significantly and does not mix with technological water. About $25 \mathrm{~m}^{3} / \mathrm{h}$ of this $\mathrm{SO}_{4}-\mathrm{Cl}-\mathrm{Na}-\mathrm{Ca}$ type water which has temperature of $38^{\circ} \mathrm{C}$ is then directed to Termy Szaflary - another popular geothermal recreation centre adjacent to the heating plant facilities. The TDS of the water is at the level of $3 \mathrm{~g} / \mathrm{dm}^{3}$. The centre was established in 2008 as the first bathing and recreation centre in Podhale dedicated only for geothermal waters. Since then, it has enhanced its recreational and hotel infrastructure.

Terma Bukovina, which also opened in 2008, is the largest and high quality-oriented geothermal recreational centre. The total area of the 12 outdoor and indoor pools is ca. 2,200 $\mathrm{m}^{2}$. The water comes from a reconstructed well from a depth of 2,390-2,605 $\mathrm{m}$ and it is a $\mathrm{SO}_{4}-\mathrm{Cl}-\mathrm{Ca}-\mathrm{Na}$ type water. The main water aquifer represents Triassic and Jurassic formations. Its TDS is $1.49 \mathrm{~g} / \mathrm{dm}^{3}$ (Chowaniec et al. 2001). While the water has a wellhead temperature of $64.5{ }^{\circ} \mathrm{C}$ (Kępińska and Wieczorek 2011), the temperature of water in pools is lower and fluctuates between 28 and $36{ }^{\circ} \mathrm{C}$, according to the pool's type. The surplus of geothermal heat obtained from the geothermal water is used 


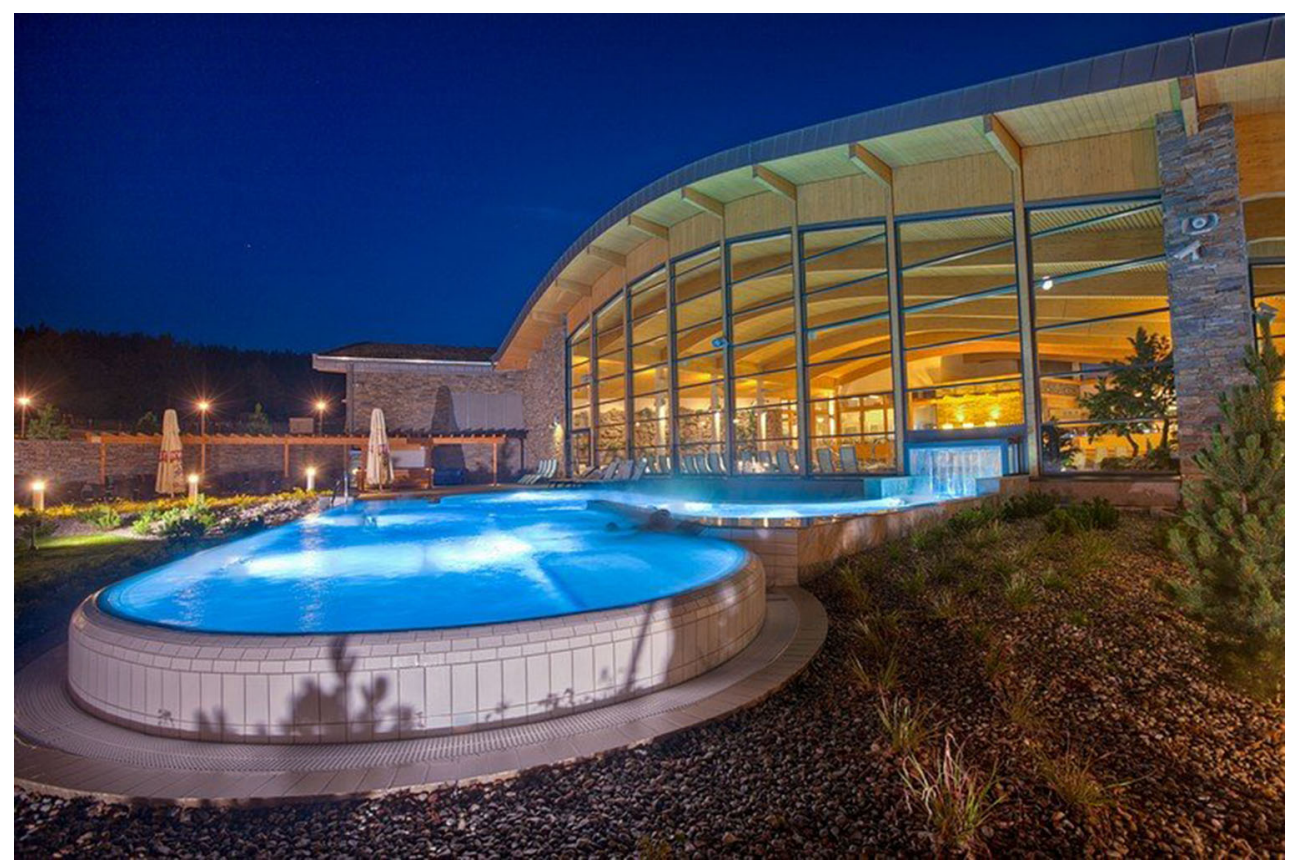

Fig. 4 Terma Białka in Białka Tatrzańska, Podhale Trough (photo: Terma Białka)

for space heating of the entire complex (including the hotel part) in combination with the heat from a heat pump and peak heat source.

Terma Białka (Fig. 4), the newest geothermal recreation centre in the Podhale region and one of the largest in Poland was opened in 2011. It is located next to a ski resort and it is complementary to other touristic attraction of the area. It can be visited by 3,000 persons a day. $\mathrm{The}^{\mathrm{SO}_{4}-\mathrm{Cl}-}$ $\mathrm{Na}-\mathrm{Ca}$ type water supplying the centre comes from a depth of ca. 2,300-2,700 m. It has a TDS of $1.8 \mathrm{~g} / \mathrm{dm}^{3}$ (http:// www.termabialka.pl, accessed 1 December 2013). The water has a temperature of $73{ }^{\circ} \mathrm{C}$. It is exploited from a single-well system, which determines special attention to the amount of water exploited and finally discharged to a course. In Terma Białka, this special attention is emphasized-the discharged water is limited to a small amount used for rinsing technological tanks only. Two heat pumps with power of ca. $700 \mathrm{~kW}$ each are installed for maximum heat extraction. This is the first working installation of heat pumps with $\mathrm{CO}_{2}$ gas used as a refrigerant in Poland.

New geothermal bathing and recreation centres in Podhale region

About $30 \%$ of the geothermal recreational centres in Poland are supplied by geothermal waters, which come from heating plants after utilizing a part of the water's energy for heating purposes. As of today, there is only one bathing centre of this kind in the Podhale region-Termy Szaflary. Meanwhile, there are plans for wider range of cooled geothermal water application from the heating plant in the second bathing centre in Szaflary, which is now underway. Apart from that centre, two more centres using the geothermal water of the Podhale geothermal system are planned in Chochołów and Poronin. Both of these locations would exploit geothermal water coming from wells where the wellhead temperature of the waters is 82 and $63{ }^{\circ} \mathrm{C}$, respectively (Kępińska and Wieczorek 2011). The temperature is too high to be used only for bathing purposes and should be used primarily for space heating purposes. The location of all the existing and planned geothermal bathing centres in the Podhale region is listed in Fig. 1.

Geothermal bathing centres in the Polish Lowlands

There are five geothermal bathing centres currently operating in the Polish Lowlands. Three of them exploit geothermal water from the Lower Cretaceous aquifer. The remaining two-Geotermia Grudziagdz and the Termy Maltańskie bathing centre in Poznań exploit water from the Lower Jurassic aquifer. Several newly planned centres will also exploit water from the Lower Jurassic aquifer at depths of 1,200-2,700 m. These centres will be located in the following towns: Gostynin, Toruń, Kleszczów, Lidzbark Warmiński, Tarnowo Podgórne, Piaseczno, Trzęsacz, in different parts of the Polish Lowlands area. Their location is given in Fig. 1. It is expected that waters used in the new centres will have outflow temperatures varying from 27 to $82{ }^{\circ} \mathrm{C}$ and a TDS of six to more than $140 \mathrm{~g} / \mathrm{dm}^{3}$ (Noga et al. 2013). 


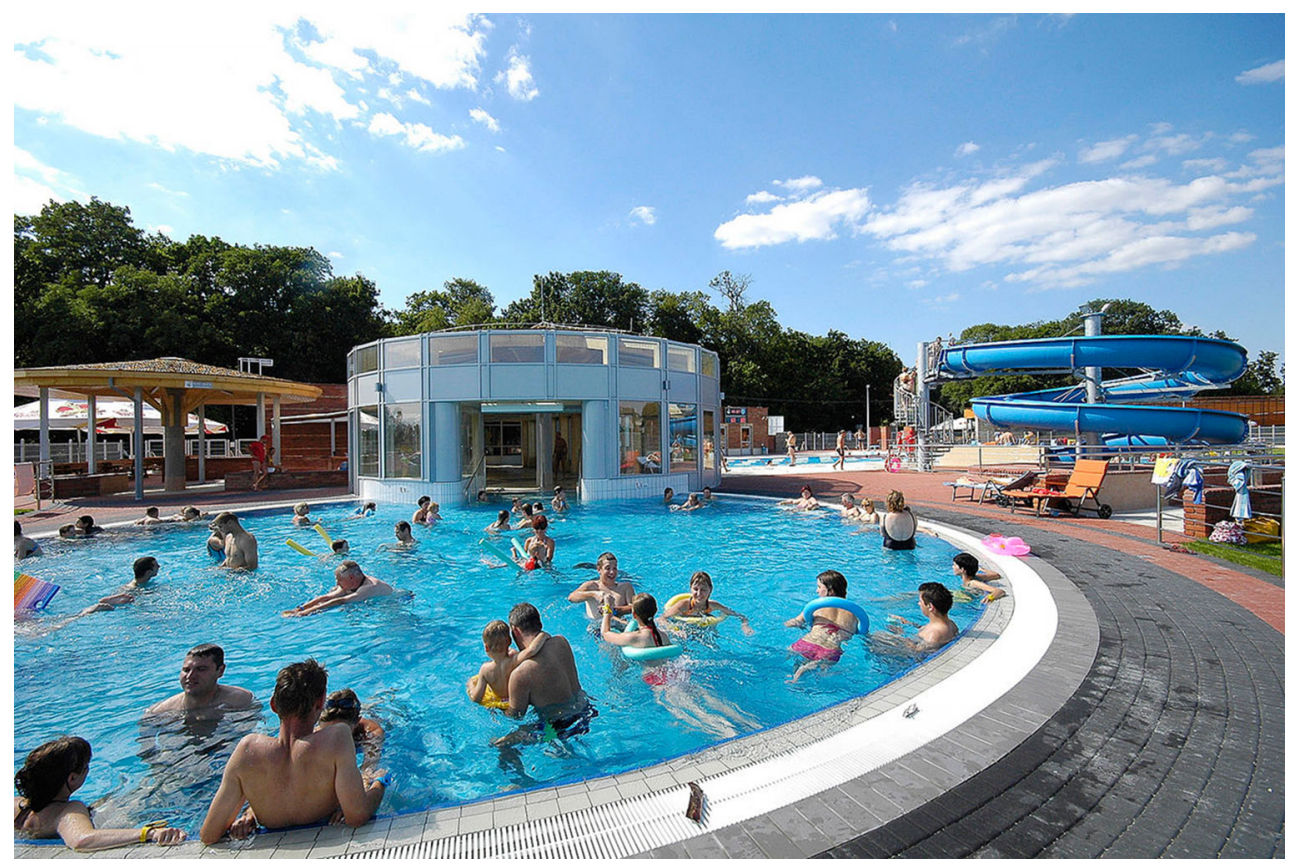

Fig. 5 Termy Uniejów in Uniejów, the central area of the Polish Lowlands (photo: Termy Uniejów)

The first geothermal bathing and therapy centre in the Polish Lowlands was Geotermia Grudziądz, where a "brine cave" providing balneotherapeutic bathing and gymnastics was initially opened in 2006. Since 2007, the centre's offer has grown and it currently offers four swimming pools filled with geothermal water, balneotherapy, cryotherapy and massage rooms. A pyramid shape graduation tower provides the possibility for inhalations by aerosols coming from the geothermal water. The water in reservoir has a temperature of $40.5^{\circ} \mathrm{C}$. It is Cl-Na type water with a TDS of ca. $79 \mathrm{~g} / \mathrm{dm}^{3}$ and it contains a significant I and Fe ions content (Krawiec 2009).

Two new geothermal centres-Termy Mszczonów and Termy Uniejów opened in 2008. Apart from their recreational application, the geothermal waters are used for space heating there. The geothermal waters come from the Lower Cretaceous aquifer; however, the geothermal water parameters differ in both centres. The water in Uniejów is exploited from a depth of ca. $2000 \mathrm{~m}$ and it has an outflow temperature of ca. $68{ }^{\circ} \mathrm{C}$. The water is $\mathrm{Cl}-\mathrm{Na}$ type. It has a relatively higher TDS comparing to the fresh water in Mszczonów. The TDS of the water varies from 6.8 to $8.8 \mathrm{~g} / \mathrm{dm}^{3}$ depending on the well (Sapińska-Śliwa and Kurpik 2011).

The geothermal water applications in Uniejów include geothermal space heating, balneorecreational swimming pools (Fig. 5), heating of football pitch grass and the operation of a geothermal health resort officially established in 2012. The geothermal bathing centre has been growing rapidly; some new outdoor swimming pools and other water attractions have been added, which allows the centre to be open all year round. At present, it offers several swimming and therapeutic brine pools with the water temperature ranging from 25 to $36{ }^{\circ} \mathrm{C}$ and saunas. The city has built the brand of a geothermal centre for recreation, spa and wellness and therapy, thanks to the geothermal waters.

The fresh water (a TDS of $0.427 \mathrm{~g} / \mathrm{dm}^{3}$ ) in Mszczonów is supplied from a single well from a depth of 1,602-1,714 $\mathrm{m}$ (Kurek 2011). After recovering the heat in the heat exchangers of the heating plant, part of the water is used as drinking water. This water is geothermal because it has a temperature of $42.5^{\circ} \mathrm{C}$. Termy Mszcznów uses the water in outdoor and indoor swimming pools, where it has temperature from 30 to $34{ }^{\circ} \mathrm{C}$. The swimming pools are filled with raw or purified geothermal water.

Similarly, in Poddębice, the geothermal water exploited from the Lower Cretaceous aquifer lying at a depth ca. $2,100 \mathrm{~m}$ is fresh water. It can be used as drinking water. A simple outdoor swimming pool filled with geothermal water was established in 2011, 2 years before the opening of the geothermal heating plant in the city. This heating plant is the most recent heating plant in Poland. Poddębice is located relatively close to Uniejów $(16 \mathrm{~km})$, where geothermal space heating and recreation have been provided as well. Despite the fact that the exploited water has a TDS of only $0.455 \mathrm{~g} / \mathrm{dm}^{3}$, it has a high temperature of $72{ }^{\circ} \mathrm{C}$. The water is a $\mathrm{HCO}_{3}-\mathrm{Na}-\mathrm{Ca}$ type (Karska and Hajto 2009). In the future, there are plans to upgrade the existing geothermal water application and provide a 
geothermal aqua park and balneological rehabilitation and recreation centre.

Termy Maltańskie in Poznań was established in 2011 as a non-geothermal aqua park dedicated exclusively for recreational and sport purposes-i.e. it has a full-size Olympic swimming pool. One of its pools was filled with water, the chemical composition of which was to be similar to brine. It was obtained as a result of dissolving salt in water. The aqua park officially became a geothermal bathing centre in May of 2013, when the geothermal water started being supplied from a well. The supplied water has a temperature of $38^{\circ} \mathrm{C}$ and the TDS is $20 \mathrm{~g} / \mathrm{dm}^{3}$ (Noga et al. 2013). It is one of the largest bathing and recreation centres in Poland.

New geothermal bathing centres in the Polish Lowlands

Several new boreholes have been drilled in recent years for geothermal purposes in the Polish Lowlands. The obtained geothermal waters of a lower temperature, but are heated additionally i.e. by heat pumps (Lidzbark Warmiński, Trzęsacz) are planned in particular to be used for balneorecreational purposes. In locations where waters have higher temperature, the waters will be used for both geothermal space heating and for bathing (Kleszczów, Gostynin, Piaseczno). Each of the boreholes in the described locations reaches the Lower Jurassic aquifer for geothermal water exploitation.

Two recent geothermal boreholes were drilled in Kleszczów in 2010-2011. They reach the aquifer at a depth of ca. 1,600 m. The water has a temperature of $52{ }^{\circ} \mathrm{C}$ and a TDS of $6.08 \mathrm{~g} / \mathrm{dm}^{3}$. The exploitation of the water will be operated as a doublet with a flow rate of $150 \mathrm{~m}^{3}$ (Noga et al. 2013). The geothermal energy will be used for heating the water of swimming pools and other sporting objects i.e. a football pitch grass. The water will be used for a recreational swimming as well. A huge geothermal recreation and balneotherapeutical centre containing 17 swimming pools has been planned in Gostynin. The geothermal water from the depth of ca. 2,700 $\mathrm{m}$ has a temperature of $82{ }^{\circ} \mathrm{C}$ at the outflow. The water has a very high TDS of $143.5 \mathrm{~g} / \mathrm{dm}^{3}$ and it contains iodine and bromine ions, which make it potentially useful for therapeutic purposes (Biernat et al. 2011). Recently, the further completion of the complex has been suspended. The geothermal water in Piaseczno located in the suburbs of Warsaw, the capital of Poland, has a lower TDS at the level of $70 \mathrm{~g} / \mathrm{dm}^{3}$ and temperature of $45^{\circ} \mathrm{C}$. The water is planned to be used for bathing in swimming pools and the space heating of sporting objects of the Termy Warszawskie. Bathing centres which will use relatively colder waters, which have temperatures at the outflow of 24 and $27^{\circ} \mathrm{C}$, respectively, and are exploited from depth of ca. 1,200 $\mathrm{m}$ are planned in
Lidzbark Warmiński and Trzęsacz. The TDS of the waters is 21 and $14 \mathrm{~g} / \mathrm{dm}^{3}$, respectively (Noga et al. 2013). Heat pumps will be intended in these geothermal projects for balneorecreation and the space heating of the objects. The implementation of the examples presented above is at an advanced stage. The borehole drilling and documentation of the resources and objects are mostly completed. These projects have also obtained funding from National Fund for Environmental Protection and Water Management and the European Union.

Geothermal bathing and recreation centres in other regions of Poland

Geothermal waters have been used for several centuries for therapeutic purposes in the Sudety Mountains (the SouthWestern part of Poland) (Wachowicz-Pyzik 2013). Three health resorts which use geothermal waters operate in the area. One of them is located in Cieplice, where the geothermal water is exploited from six springs and shallow wells. Two additional deep wells were drilled in the 1970s. Only one of them supplies the health resort with water of a temperature of $63.3^{\circ} \mathrm{C}$. However, construction works are underway to use geothermal water for recreation purposes in Cieplice, from the second, deeper well, where the curative water has a temperature of $86.7^{\circ} \mathrm{C}$ at the outflow. The flow rate of the water from the depth of $2,002.5 \mathrm{~m}$ is $45 \mathrm{~m}^{3} / \mathrm{h}$. It is a $\mathrm{SO}_{4}-\mathrm{HCO}_{3}-\mathrm{Na}$ type water with significant $\mathrm{F}$ and Si ions content (Ciężkowski 2011). The centre will include three swimming pools with connections to outdoor pools, pools for children, water slides and saunas.

Additional geothermal bathing centres are planned in Olsztyn (near Częstochowa), Jaworze, Poręba Wielka and Celejów, each located in the southern part of Poland. All the locations of the planned centres are given in Fig. 1. The progress of these projects is relatively low and dependent on future funds.

A major concentration of geothermal recreational centres is observed in the Podhale region. Most of centres were opened in 2008, two in Podhale Trough and another two in the Polish Lowlands. Their size differs from small ones, intended mainly for treatment or wellness, but not being an official health resort (Geotermia Grudziądz), to large complexes with extensive offers, dozens of swimming pools and other water attractions (Terma Bukovina, Terma Białka).

Geological and technical parameters of the occurrence and application of waters, which are delivered to Polish geothermal recreational centres, are presented in Table 1. The wellhead temperature of waters ranges from 27.3 to $82{ }^{\circ} \mathrm{C}$ and this is the lowest and the highest temperature of water used for recreational purposes. Only in two wells (No. 2 and No. 10), water is exploited from the depth lower 


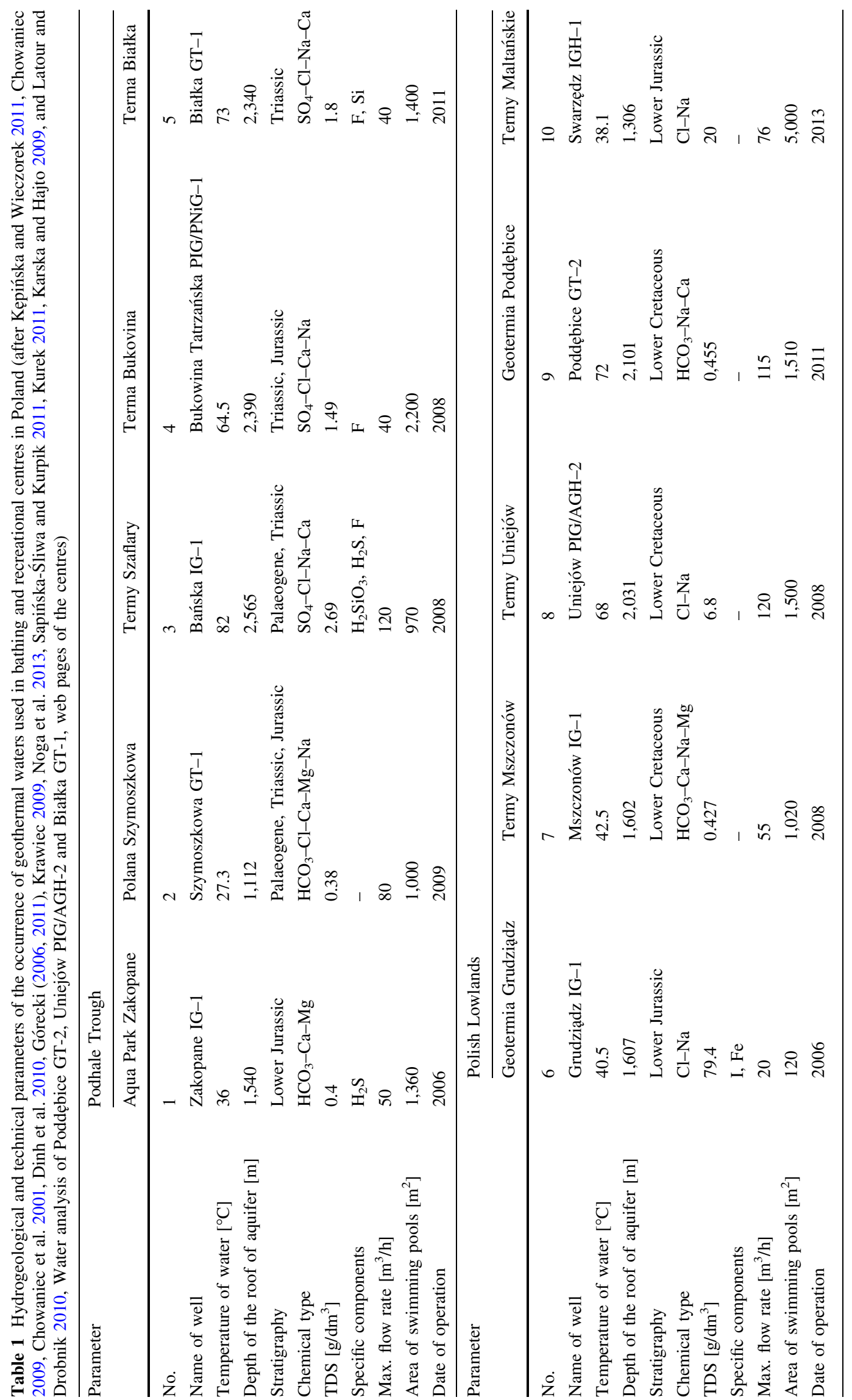


Fig. 6 Diagrams showing location, TDS (mineralization) and major ions content of water used in the existing bathing and recreational centres in Poland. The sizes of circles reflect the TDS level

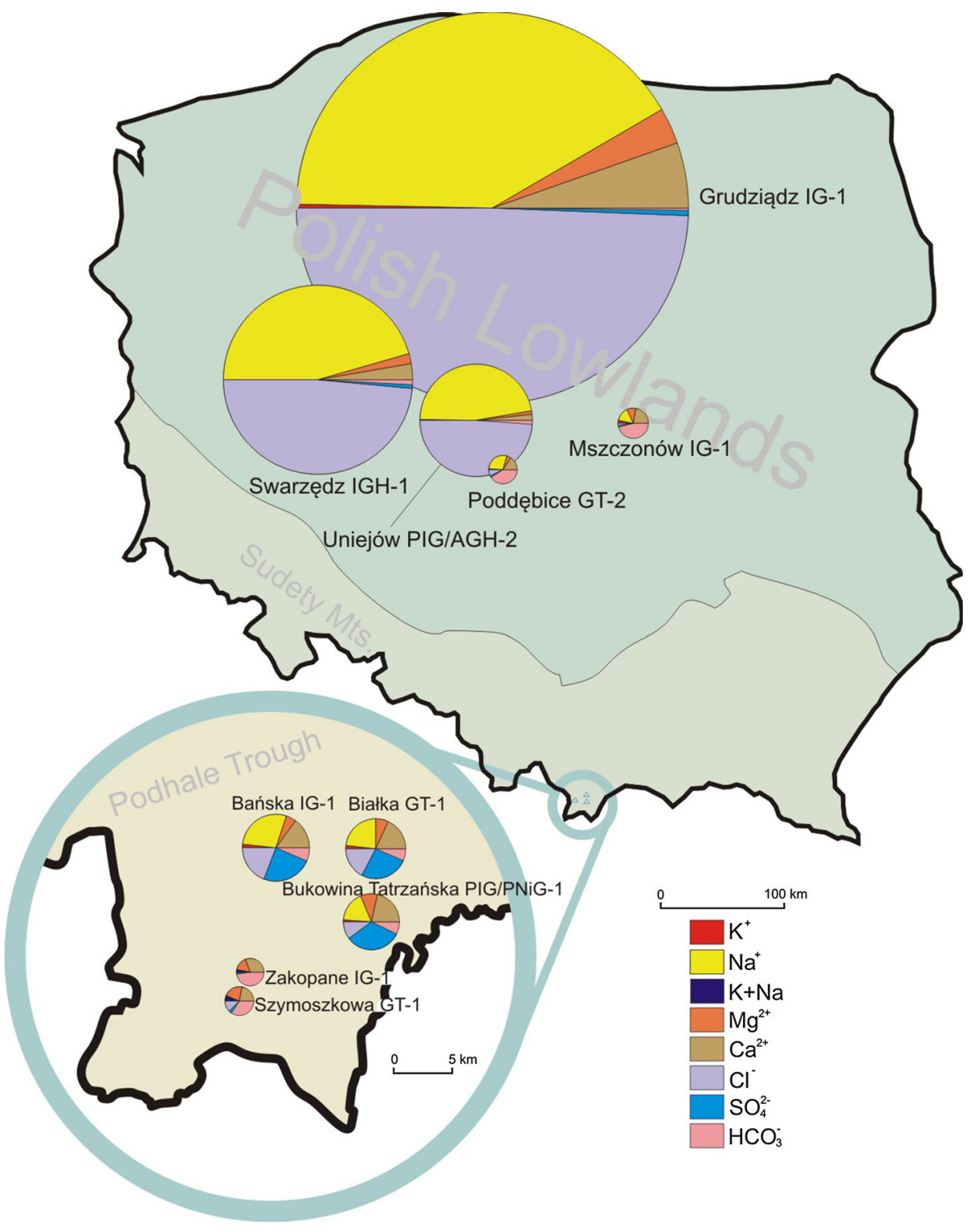

than 1,500 m. In well No. 2, where the roof of exploited aquifer is located at the lowest depth, water has the lowest temperature of all waters used for recreational purposes $\left(27.3{ }^{\circ} \mathrm{C}\right)$. Waters come mostly from the depths exceeding $1,500 \mathrm{~m} .50 \%$ of all exploited aquifers lie deeper than $2,000 \mathrm{~m}$, and water from these aquifers has the temperature of $68-82{ }^{\circ} \mathrm{C}$. Water from Palaeogene-triassic aquifer has the highest temperature of all wells under consideration. The roof of this aquifer has the depth of ca. 2,500 $\mathrm{m}$ in well No. 3, which is also used for a district heating facility.

Geothermal recreational centres of the Polish Lowlands exploit Lower Jurassic and Lower Cretaceous aquifers. They are recognized as the most prospective aquifers of the Polish Lowlands (Górecki 2006). Centres of the Podhale Trough exploit Triassic, Jurassic and Palaeogene aquifers. In Table 1, flow rates of the waters are listed. The final flow rate for bathing purposes may be lower if used concurrently for several applications (e.g. Termy Szaflary).

The TDS of water ranges from $0.4 \mathrm{~g} / \mathrm{dm}^{3}$ in well No. 2 to ca. $80 \mathrm{~g} / \mathrm{dm}^{3}$ in well No. 6. Generally, waters from the Podhale Trough used for recreation have low TDS, which does not exceed $3 \mathrm{~g} / \mathrm{dm}^{3}$. On the other hand, water in the Polish Lowlands differs significantly and TDS values differ from those characteristic for fresh water (No. 7 and No. 9), to a high TDS value, which is characteristic for concentrated brines (No. 6). The TDS level and the share of main anions of waters from the centres are shown in Fig. 6 . Especially interesting are waters from areas of mineralization inversion, where deep aquifers are reached in waters, and TDS is much lower than expected from a hydrogeochemical gradient, such as e.g. in wells No. 7 and No. 9. Water from the wells has TDS of fresh water, even it 
Fig. 7 Schoeller diagram of geothermal waters used in bathing and recreational centres in Poland

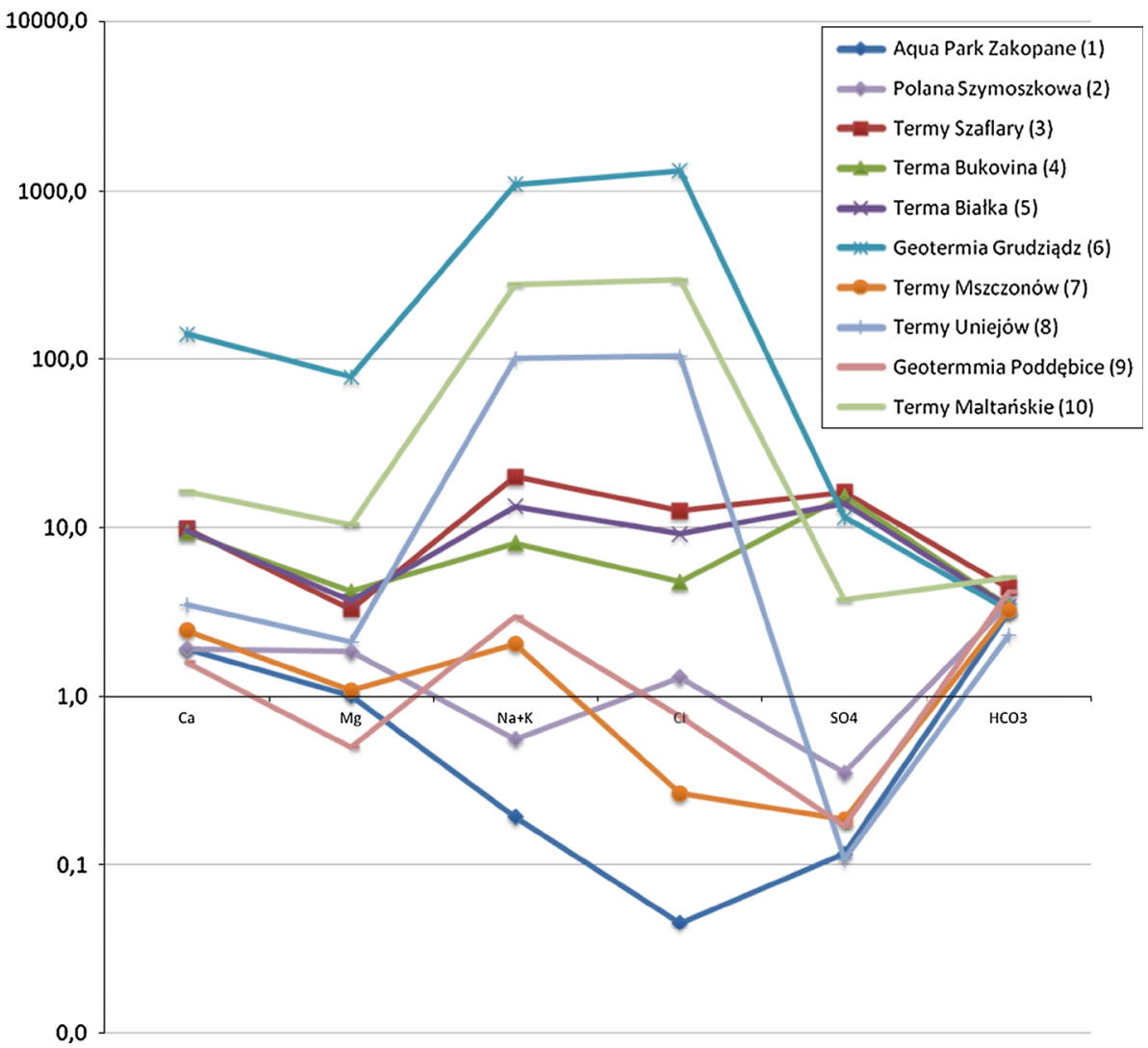

comes from the depth of more than $1,500 \mathrm{~m}$. These are waters in which $\mathrm{HCO}_{3}{ }^{-}$is a dominant ion. After decreasing water temperature from well No. 7 in district heating facilities, water is partially used in a drinking water supply system in Mszczonów.

If compared, wells No. 8 and No. 9 are located at a short distance and in the same geological subunit of the Polish Lowlands. However, water from well No. 9 has low TDS $\left(0.455 \mathrm{~g} / \mathrm{dm}^{3}\right)$, even though it comes from the same formation and similar depth as water from well No. 8, in which TDS is higher and its value is $6.8 \mathrm{~g} / \mathrm{dm}^{3}$. Moreover, the hydrochemical type of waters differs. Water from well No. 9 is of $\mathrm{HCO}_{3}-\mathrm{Na}-\mathrm{Ca}$ type, while water from well No. 8 is $\mathrm{Cl}-\mathrm{Na}$ type.

Main chemical components of waters used for recreational purposes in both geological units are compared in semi-logarithmic Schoeller diagram (Schoeller 1962; Mazor 2004) in Fig. 7. The diagram shows similar chemical characteristics of waters from wells No. 6, No. 10 and No. 8 (the Polish Lowlands), in which the main ion content is decreasing in a given order. The above-mentioned waters have revealed similar peaks of ions. Additionally, in waters from well No. 6, some elements significant in medicine (I and $\mathrm{Fe}$ ) were determined. There is no correlation of peaks of the main ions between waters from wells No. 9 and No. 7 , despite the fact that they are both of $\mathrm{HCO}_{3}$ type and have a very low TDS level. They come from different geological subunits and the depth of their aquifers occurrence differs as well. Geothermal waters of the Polish Lowlands are generally low in $\mathrm{Mg}$ and $\mathrm{SO}_{4}$ and high in $\mathrm{Na}$ and $\mathrm{Cl}$ concentrations. All waters under analysis have a similar level of $\mathrm{HCO}_{3}$ ions content.

In the area of the Podhale Trough, waters from wells No. 3, No. 4 and No. 5 revealed a similar chemical type. Those waters are of $\mathrm{SO}_{4}-\mathrm{Cl}-\mathrm{Na}-\mathrm{Ca}$ or $\mathrm{SO}_{4}-\mathrm{Cl}-\mathrm{Ca}-\mathrm{Na}$ type. Some specific components of $\mathrm{F}, \mathrm{Si}$, or $\mathrm{H}_{2} \mathrm{~S}$ were determined (Table 1). Despite a similar water type, the waters differ in terms of a TDS level. Geothermal waters of the Podhale Trough are generally low in $\mathrm{Mg}$ and $\mathrm{HCO}_{3}$ and high in $\mathrm{SO}_{4}$ concentrations. There was no such correlation observed in waters from wells No. 1 and No. 2, which are exploited from lower depths and are located at a shorter distance from the system recharge area.

\section{Conclusion}

Geothermal waters used in the recreational centres in Poland represent two different geological units: the Podhale Trough and the Polish Lowlands, occupying a much larger area. In each unit, five centres are located. Waters determined by various parameters are used in bathing and recreation facilities.

Waters of the Podhale Trough are mostly of $\mathrm{SO}_{4}-\mathrm{Cl}-$ $\mathrm{Na}-\mathrm{Ca}$ or $\mathrm{SO}_{4}-\mathrm{Cl}-\mathrm{Ca}-\mathrm{Na}$ type and their TDS does not 
exceed $3 \mathrm{~g} / \mathrm{dm}^{3}$ Waters from depths below 2,000 m have the highest wellhead temperatures between those connected with recreation centres. In the area, there is also a centre which exploits waters with the lowest wellhead temperature of $27.3{ }^{\circ} \mathrm{C}$. Bathing and recreational centres in the Trough are concentrated on a smaller area, compared with the Polish Lowlands; however, the area is much more attractive from the touristic point of view. The area occupied by the centres is ca.1,000 $\mathrm{m}^{2}$. The largest one, Terma Bukovina, occupies the area of more than $2,000 \mathrm{~m}^{2}$.

Flow rates and TDS of waters from the Polish Lowlands vary. TDS ranges from very high to characteristic for fresh waters, despite coming from depths exceeding 1,300 m. All waters come from Lower Jurassic or Lower Cretaceous aquifers. Geothermal waters of the Polish Lowlands are generally high in $\mathrm{Na}$ and $\mathrm{Cl}$ concentrations. Recreational centres are located mostly in the central part of the Lowlands. The surface area of the centres ranges from very small to large, where both geothermal and non-geothermal waters are used.

Good geothermal conditions also occur in the Sudety Mountains; however, the geothermal waters there are mostly limited for use in health resorts for therapy. The geothermal water in bathing and recreation centres is used for filling the pools. Geothermal energy from water is also used for space heating of swimming pools or other facilities. In some locations, heat pumps are installed for providing additional heating of the water or for space heating. Some new projects of geothermal bathing and recreation centres are planned in different areas of Poland, but their implementation progress is generally lower.

Acknowledgments The author would like to thank the "GEOS" Geosynoptic Society for the financial support of attendance on CMTW meeting Budapest 2012.

Open Access This article is distributed under the terms of the Creative Commons Attribution License which permits any use, distribution, and reproduction in any medium, provided the original author(s) and the source are credited.

\section{References}

Antics M, Bertani R, Sanner B (2013) Summary of EGC 2013 country update reports on geothermal energy in Europe. Proceedings of the european geothermal congress 2013. Pisa, Italy, pp 1-19

Biernat H, Kapuściński J, Noga B (2011) Review of ongoing and planned projects the use of geothermal water and energy for the Polish Lowland (in Polish). Proceedings of the third national congress of geothermal, Ladek Zdroj (CD)

Bojarski L, Płochniewski Z, Stachowiak J (1976) Thermal waters of the polish lowlands (in polish). Geol Quart 20(3):657-672

Chowaniec J (2004) Hydrogeological properties of the Podhale flysch (central western carpathians, Poland) in the light of studies on water storage capacity. Geol Carpath 55(1):77-81
Chowaniec J (2009) Hydrogeology study of the western part of the polish carpathians. Bull Pol Geol Inst 434:1-98

Chowaniec J, Długosz P, Drozdowski B et al (1997) Hydrogeological documentation of thermal water resources of the Podhale Trough (in Polish). Arch. Geol. Państw. Inst. Geol., Oddz. Karpacki, Kraków, Centr

Chowaniec J, Poprawa D, Witek K (2001) Occurrence of thermal waters in Polish part of the carpathians. Geol Rev 49(8):734-742

Ciężkowki W (2011) Geothermal waters in lower silesia (in Polish). In: Żelażniewicz A, Wojewoda J, Ciężkowski W (eds) Mesozoic and Cenozoic of Lower Silesia. WIND, Wrocław, pp 107-120

Ciężkowski W, Chowaniec J, Górecki W, Krawiec A, Rajchel L, Zuber A (2010) Mineral and thermal waters of Poland. Geol Rev 58(9/1):762-773

Dinh CN et al. (2010) Natural radioactivity of thermal waters of the Podhale Trough-preliminary results (in Polish). In: Proceeding of Science and management of Tatra Mts. area, Zakopane, pp 111-114

Dowgiałło J (2012) Occurrence and use of mineral and thermal waters in Poland. Environ Earth Sci 67:2251-2259

Dowgiałło J, Karski A, Potocki I (1969) Geology of balneological resource (in Polish). Wyd Geol, Warszawa

Dowgiałło J, Kaczor D, Porowski A (2007) Thermal brines of the Polish Lowlands in the light of latest investigations (in Polish). Contemp Probl Hydrogeol 13:53-63

Górecki W (ed) (1995) Atlas of geothermal energy in the Polish Lowlands. ZSE AGH, Towarzystwo Geosynoptykow GEOS, Krakow

Górecki W (ed) (2006) Atlas of geothermal resources of Mesozoic formations in the Polish Lowlands, Kraków

Górecki W (ed) (2011) Atlas of geothermal waters and energy resources in the Western Carpathians, Kraków

Hajto M (2006) Geological cross-section through the Polish Lowlands. In: Górecki W (ed) Atlas of geothermal resources of Mesozoic formations in the Polish Lowlands, Kraków

Karska A, Hajto M (2009) Possibilities of utilization of geothermal waters in the area of Poddębice city (in Polish). Geological Exploration Technology Geothermics Sustainable Development 2:89-99

Kępińska B (1997) Geological-geothermal model of the Podhale Trough (in Polish). Inst Min Res Energy Econ, PAS, Kraków. Studies, Dissertations, Monographs, 48

Kępińska B (2001) Thermal Springs and Spas in Poland. In: Proceedings of International Workshop on balneology and "water tourist centers". Bad Urach, Germany 1.6

Kępińska B (2006) Thermal and hydrothermal conditions of Podhale geothermal system (Poland) (in Polish). Inst Min Res Energy Econ, PAS, Kraków. Studies, Dissertations, Monographs. 135

Kępińska B (2013) Geothermal energy use, country update for Poland. Proceedings of the European Geothermal Congress 2013. Pisa, Italy, pp 1-10

Kępińska B, Łowczowska A (2002) Geothermal waters in therapy, recreation and touristic (in Polish). Inst Min Res Energy Econ, PAS, Kraków

Kępińska B, Wieczorek J (2011) Hydrogeological conditions of occurrence of geothermal waters in the Western Carpathians. In, Górecki W (ed) Atlas of geothermal waters and energy resources in the Western Carpathians, Kraków, pp 104-108

Krawiec A (2009) Thermal waters in the vicinity of Grudziądz (in Polish). Geological Exploration Technology Geothermics Sustainable Development 2:81-88

Kriš J (2005) Geothermal Waters in Recreational Facilities of Slovakia. Proceedings of International Symposium on Water Management and Hydraulic Engineering, Ottenstein, Austria 03:377-382

Kriš J, Marton J, Skultétyová I (1995) Mineral and Geothermal Waters of Slovakia. GeoJournal 35(4):431-442 
Kurek J (2011) Geothermal energy and balneology as a real possibility for development of municipalities. Renewable Sources of Energy for urban development. Mszczonow municipality (in Polish). In: Presentation from II European Economic Congress Katowice. http://www.wnp.pl/pliki/3568_22451.html. Accessed 1 December 2013

Latour T (2007) Actual status and further possibilities for application of thermal waters in therapy, preventive therapy and recreation (in Polish). Geological Exploration Technology Geothermics Sustainable Development 240:63-67

Latour T, Drobnik M (2010) Possibilities for application of thermal waters in the Wielkopolska area for therapeutic and recreational purposes (in Polish). Geol Rev 58(7):609-612

Lund JW, Freeston DH, Boyd TL (2011) Direct utilization of geothermal energy 2010 worldwide review. Geothermics 40:159-180

Małecka D (2003) The thermal waters of Podhale, southern Poland: history of research, genesis and utility. Geol Quart 47(2): 195-209
Mazor E (2004) Chemical and Isotopic Groundwater Hydrology. Mercel Dekker, Inc., New York

Noga B, Biernat H, Kapuściński J et al (2013) Possibility of obtaining more geothermal heat in the view of the new investments completed in Poland (in Polish). Geological Exploration Technology Geothermics Sustainable Development 2:75-85

Paczyński B, Sadurski A (2007) Regional hydrogeology of Poland (in Polish). National Geological Institute, Warszawa

Sapińska-Śliwa A, Kurpik J (2011) Current management of water and geothermal heat in Uniejow (in Polish). Geological Exploration Technology Geothermics Sustainable Development 1-2: $225-235$

Schoeller H (1962) Les eaus souterrians Masson et. Cie, Paris

Wachowicz-Pyzik A (2013) Current directions of using geothermal energy in Poland. In: Buczyński S, Staśko S, Huszcz B (eds) Geothermic: IV international field workshop for young hydrogeologists, Lądek-Zdrój, Agencja Wydawnicza,ARGI sc, pp 63-72 